\title{
Induced Resistance in Potato against Late Blight Caused by Phytophthora infestans (Mont.) De Bary, Through Calcium Chloride
}

\author{
Surjeet Kumar, S.K. Biswas*, Virendra Kumar, Kishan Lal, \\ Anuj Bansal and V. Tilak Chowdary
}

\author{
Department of Plant Pathology, C.S. Azad University of Agriculture and Technology, \\ Kanpur- 208002, India \\ *Corresponding author
}

\begin{tabular}{|c|c|}
\hline & A B S T R A C T \\
\hline Keywords & $\begin{array}{l}\text { An experiment was conducted to evaluate calcium chloride }\left(\mathrm{CaCl}_{2}\right) \text { as inducers in } \\
\text { induce resistance against late blight of potato caused by Phytophthora infestans. }\end{array}$ \\
\hline $\begin{array}{l}\text { Resistance, } \\
\text { Potato, Late } \\
\text { blight, Calcium } \\
\text { Chloride. }\end{array}$ & $\begin{array}{l}\text { Two per cent } \mathrm{CaCl}_{2} \text { used in } 9 \text { treatments for different time durations }(1 / 2 \mathrm{~h}, 1 \mathrm{~h} \text {, } \\
2 \mathrm{~h}, 4 \mathrm{~h}, 6 \mathrm{~h}, 8 \mathrm{~h}, 10 \mathrm{~h}, 12 \mathrm{~h} \text { and } 0 \mathrm{~h}) \text { and foliar spray and resulted that } \mathrm{CaCl}_{2} \text { have } \\
\text { ability to reduce disease severity from } 22.65 \text { to } 48.00 \text { per cent against } 57.00 \text { per } \\
\text { cent in case of control. Biomolecules changes due to effect of } \mathrm{CaCl}_{2} \text { revealed that }\end{array}$ \\
\hline Article Info & $\begin{array}{l}\text { increase content of soluble protein and total phenol content with the minimum in } \\
\mathrm{T}_{8} \text { treatment representing } 32.5,34.5,34.5,34.5,33.1 \mathrm{mg} / \mathrm{g} \text { fresh leaf of soluble }\end{array}$ \\
\hline $\begin{array}{l}\text { Accepted: } \\
\text { 04 June } 2017 \\
\text { Available Online: } \\
10 \text { August } 2017\end{array}$ & $\begin{array}{l}\text { protein, and } 2.57,2.62,2.74,2.87 \text { and } 2.78 \mathrm{mg} / \mathrm{g} \text { fresh leaf of total phenol at } 2,4 \text {, } \\
6,8 \text { and } 10 \text { days of pathogen inoculation. The correlation coefficient between } \\
\text { disease severity with total soluble protein and total phenol content showed } \\
\text { negative correlation in both cases. }\end{array}$ \\
\hline
\end{tabular}

\section{Introduction}

Potato (Solanum tuberosum L.) is the most important and useful vegetable crop in the world, belonging to the family Solanaceae. It is the world's fourth-largest food crop, following maize, wheat and rice. China stands top at the list with around $23 \%$ of the world's potato produces that is around 322 million metric tonns. In world scenario, India became the $3^{\text {rd }}$ largest producer of potato (Scott and Suarez, 2011).

The production and productivity of potato in India is impressive. However, in the background of increasing population pressure, there is a need to increase productivity from same piece of land. But the main reason of low productivity is diseases like, early blight, late blight, leaf spot, dry rot, charcoal rot, black scurf, common scab, soft rot, leaf roll etc. Among them, late blight caused by Phytophthora infestans (Mont.) de Bary is most destructive disease that had led to most in-famous catastrophe in Ireland (England) during 1840-1845. The pathogen is mainly perpetuated in tuber and soil through production of oospores. The management of the disease can be done through host resistance, cultural adjustments, biological and use of fungicides. But most of the conventional chemicals, biological and use of 
resistance varieties tend towards the direct control of pathogens by their elimination. Sometimes these practices raise problem due to development of resistant strains of the pathogen which may become very difficult to control. Induced resistance is a new area of extensive work aiming at developing new strategies for disease control meeting the requirements for safe application in greenhouse and fields conditions, namely: no direct toxicity to pathogens; no toxicity to plants and animals; no negative effects on plant growth, development and yield; broad spectrum of defense; low loading amount; long lasting protection; low economical cost for 64 Aglika Edreva farmers; good profit for producers (Kuc, 2001). Several inorganic chemicals, bio agents, plant extract, secondary metabolites etc. have been used as inducers in management of several diseases in different crops (Biswas et al., 2012, Rajik et al., 2012 and Arzoo et al., 2012).

The mechanism of resistance was found in association of some defense compounds like soluble protein, total phenol and synthesis of some new proteins due to the effect of biotic inducers (Rajik et al., 2012). Biswas et al., (2003) found that pre-application of crude extract of Chaetomium globosum provided induced resistance in wheat against spot blotch and also sensitized the plant to produce evaluated level of total phenol soluble protein and some new proteins of different molecular level. Considering that above point on view the study was undertaken in the present investigation as "Induced resistance in potato against late blight disease caused by Phytophthora infestans (Mont.) de Bary, through calcium chloride".

\section{Materials and Methods}

\section{Isolation and purification of pathogen}

Infected plant sample sowing typical late blight symptoms was collected from
Vegetable Research Farm, CSAUA\&T, Kanpur for isolation and purification of pathogen. Small pieces of infected leaf along with some green healthy tissues were cut and dipped in $\mathrm{HgCl}_{2}(0.1 \%)$ solution for 30 seconds. The pieces were then rinsed in sterilized distilled water thrice and dried off with sterilized filter paper. These pieces were placed on tomato extract based medium (selective medium) in Petri plates and then incubated at $18 \pm 1^{\circ} \mathrm{C}$. The Petri plates were observed daily to notice the presence of mycelium around the leaf bit. As soon as the mycelia growth is noticed around the bits, pathogen was purified by hypha tip culture method and characterized based on cultural and morphological characteristics.

\section{Preparation of $\mathrm{CaCl}_{2}$ solution}

Twenty gram of $\mathrm{CaCl}_{2}$ was mixed in a beaker along with $1000 \mathrm{ml}$ of distilled water to prepare $2 \%$ concentration solution of $\mathrm{CaCl}_{2}$. The solution was then used for further study as tuber treatment and foliar spray.

\section{Experiment}

The experiment was conducted in the wire house complex, Department of Plant Pathology, C. S. Azad University of Agriculture and Technology, Kanpur. The seed tuber of potato variety 'Kufri Lalima' was treated with solution of $\mathrm{CaCl}_{2}$ and spraying on plants with the same at 45 days age of plant. The details of treatment are given in table 1

The treated tubers were sown in $30 \mathrm{~cm}$ earthen pots which were previously filled with a mixture of sterilized sandy loam soil and farm yard manure in the ratio of 2:1. In each pot, one seed tuber was sown and watered as per need base. The experimental design was laid out in simple CRD. Three replications per treatment and three pots were sown with untreated seed tubers served as control. The 
observations pertaining to the effect of different treatments were taken on disease severity and biochemical changes occur during pathogenesis.

Effect of calcium chloride $\left(\mathrm{CaCl}_{2}\right)$ on disease development

\section{Spraying of calcium chloride}

In order to determine the efficacy of Calcium chloride as seed treatment and foliar spray in controlling disease, at 45 days age, the plants were sprayed first with solution of calcium chloride separately.

\section{Inoculation of the crop}

After 48 hours, plants were inoculated with spore suspension of $P$. infestans. The concentration of spore was maintained at $10^{6}$ spore/ $\mathrm{ml}$.

The spore suspension was prepared from seven days old culture of the pathogen. The homogenized, spore suspension were inoculated on the foliage of each plant. The inoculated plants were then kept on the bench of wire house. After 2, 4, 6 and 10 days, observations were taken on disease severity.

\section{Measurement of disease severity}

Observations for measuring the disease severity were taken after 5 days of pathogen inoculation. The disease severity was recorded on a 0-9 scale as described by Malcolimson, (1976). Ten leaves were randomly selected from the pot for measurement of disease severity. The leaves with $1-9 \%$ infection received $1,10 \%$ infection received $2,11-25 \%$ infection received 3,26 $40 \%$ infection received $4,41-60 \%$ infection received $5,61-70 \%$ infection received 6,71 $80 \%$ infection received $7,81-90 \%$ infection received 8, 91-100\% infection received 9 (Malcilimson, 1976).
The disease severity of individual plants was calculated by following formula:-

Disease severity PDI $=\sum$

Sum of numerical rating x 100

Total number of leaves examined $\mathrm{x}$ Maximum rating

\section{Effect of $\mathrm{CaCl}_{2}$ on changes of biomolecules} in potato during pathogenesis

In order to find out the changing biomolecules to effect of $\mathrm{CaCl}_{2}$ the fresh potato leaves were collected from different treatments and the changes in the content of soluble protein and total phenol in leaves were estimated at 2, 4, 6,8 and 10 days after pathogen inoculation.

\section{Soluble protein estimation}

Total soluble protein content was determined as per method described by Lowery et al., (1951).

\section{Total phenol estimation}

The accumulation of phenols in potato plants after treatment with $\mathrm{CaCl} \quad 2$ followed by inoculation of pathogen was estimated following procedure developed by Bary and Thrope (1954). In this method , the total phenol estimation was carried out with FCR which was measured at $650 \mathrm{~nm}$ radiation calorimetrically.

\section{Correlation coefficient and regression equation}

The bio molecule changes in potato leaves under different treatment $\mathrm{s}$ and disease severity of the corresponding date showed that reduced disease severity was associated with increased soluble protein and total phenol content. However, to determine the level of association correlation coefficients (r) 
between soluble protein and disease severity as well as between total phenol and disease severity were calculated by standard statistical calculation.

Simple regression equation ( $\quad Y=a+b x$ ) were also developed for both the variable (protein and phenol) separately to understand their relation with disease severity.

\section{Results and Discussion}

\section{Effect of calcium chloride as inducer on severity of late blight of potato}

The effect of tuber treatment and foliar spray with calcium chloride as inducers significantly reduced disease severity of late blight of potato as compared to control (Table 3).

Among the treatments, the minimum disease severity with $15.90 \%, 20.70 \%$ and $22.65 \%$ were recorded in $\mathrm{T}_{8}$ treatment at 2, 6 and 10 days after pathogen inoculation, respectively followed by $\mathrm{T}_{7}$ treatment as $16.70 \%, 21.87 \%$ and $23.35 \%$ and $\mathrm{T}_{6}$ treatments $16.95 \%$, $22.68 \%$ and $24.08 \%$.

From the table, it is also cleared, that all the inducer treated potato plants were showing comparatively low disease severity over control.

The decrease in disease severity might be the activity of calcium chloride as inducer which stimulates to synthesis of some defence related compounds in potato plant against $P$. infestans. Several workers also reported that application of biotic and abiotic inducers reduce disease severity in rice (He et al., 2002, Selein et al., 2011, Girdhari et al., 2010), in tomato against Fusarium wilt (Arzoo et al., 2010, Biswas et al., 2012), in wheat against Spot blotch (Mishra et al., 2011) (Table 2).
Biochemical changes associated with the effect of calcium chloride as inducer during pathogenesis at different days

Biochemical changes like total soluble protein, total phenol content due to effect of calcium chloride as inducers were studied as pre inoculation method and changing biomolecules were estimated at 2, 4, 6, 8 and 10 days after pathogen inoculation.

\section{Soluble proteins}

The data presented in table 4 showed that the maximum amount of soluble protein contents was found in $T_{8}$ treatment, representing the value $32.50 \mathrm{mg} / \mathrm{gm}$ of fresh leaves, $34.53 \mathrm{mg} / \mathrm{gm}$ of fresh leaves, $34.50 \mathrm{mg} / \mathrm{gm}$ of fresh leaves, $34.68 \mathrm{mg} / \mathrm{gm}$ of fresh leaves, $33.10 \mathrm{mg} / \mathrm{gm}$ of fresh leaves of fresh leaves at $2,4,6,8$ and 10 days of pathogen inoculation. The soluble protein contents in control plant were $21.87 \mathrm{mg} / \mathrm{gm}$ of fresh leaves, $23.75 \mathrm{mg} / \mathrm{gm}$ of fresh leaves, $23.85 \mathrm{mg} / \mathrm{gm}$ of fresh leaves, $24.15 \mathrm{mg} / \mathrm{gm}$ of fresh leaves, and $23.44 \mathrm{mg} / \mathrm{gm}$ of fresh leaves at 2,4,6,8 and 10 days of pathogen inoculation. The $T_{7}$ treatment representing the value of soluble protein as $32.42 \mathrm{mg} / \mathrm{gm}$ of fresh leaves, 34.33 $\mathrm{mg} / \mathrm{gm}$ of fresh leaves, $34.41 \mathrm{mg} / \mathrm{gm}$ of fresh leaves, $34.58 \mathrm{mg} / \mathrm{gm}$ of fresh leaves and $33.05 \mathrm{mg} / \mathrm{gm}$ of fresh leaves at 2,4,6,8 and 10 days of pathogen inoculation which is second highest among the treatments. The per cent increased soluble protein content was ranges 37.96 to 41.21 , indicating all the treated plants were able to synthesized soluble protein in plant. Antoniew et al., (1980) considered that pathogen related proteins (PR protein) in the form of chitinase, PR-1, peroxides, $\beta$-glycosidase etc. are involved in plant defence response to pathogens. Biswas et al., (2012) found that pre-foliar spray with inorganic chemicals increases soluble protein content in tomato resulted decline in disease incidence of wilt. Singh and Prithviraj (1977) 
also found that neemazol, a product of neem increased protein in pea leaves against Erysiphe pisi. Chakraborty and Sharma
(2007) reported that neem leaf extract caused accumulation of polyphenol and PR-protein (Satesh Kagale et al., 2004).

Table.1 Details of treatment

\begin{tabular}{|l|l|}
\hline $\mathrm{T}_{1}$ & Seed tuber treatment with $\mathrm{CaCl}_{2}$ solution @ $2.0 \%$ for $1 / 2 \mathrm{~h}+$ spraying with $\mathrm{CaCl}_{2}$ \\
\hline $\mathrm{T}_{2}$ & Seed tuber treatment with $\mathrm{CaCl}_{2}$ solution @ $2.0 \%$ for $1 \mathrm{~h}+$ spraying with $\mathrm{CaCl}_{2}$ \\
\hline $\mathrm{T}_{3}$ & Seed tuber treatment with $\mathrm{CaCl}_{2}$ solution @ $2.0 \%$ for $2 \mathrm{~h}+$ spraying with $\mathrm{CaCl}_{2}$ \\
\hline $\mathrm{T}_{4}$ & Seed tuber treatment with $\mathrm{CaCl}_{2}$ solution @ $2.0 \%$ for $4 \mathrm{~h}+$ spraying with $\mathrm{CaCl}_{2}$ \\
\hline $\mathrm{T}_{5}$ & Seed tuber treatment with $\mathrm{CaCl}_{2}$ solution @ $2.0 \%$ for $6 \mathrm{~h}+$ spraying with $\mathrm{CaCl}_{2}$ \\
\hline $\mathrm{T}_{6}$ & Seed tuber treatment with $\mathrm{CaCl}_{2}$ solution @ $2.0 \%$ for $8 \mathrm{~h}+$ spraying with $\mathrm{CaCl}_{2}$ \\
\hline $\mathrm{T}_{7}$ & Seed tuber treatment with $\mathrm{CaCl}_{2}$ solution @ $2.0 \%$ for $10 \mathrm{~h}+$ spraying with $\mathrm{CaCl}_{2}$ \\
\hline $\mathrm{T}_{8}$ & Seed tuber treatment with $\mathrm{CaCl}_{2}$ solution @ $2.0 \%$ seed for $12 \mathrm{~h}+$ spraying with $\mathrm{CaCl}_{2}$ \\
\hline $\mathrm{T}_{9}$ & No seed tuber treatment $($ Control) \\
\hline
\end{tabular}

Table.2 Effect of calcium chloride as inducer on disease severity of late blight of potato

\begin{tabular}{|c|c|c|c|c|}
\hline \multirow{2}{*}{ Treatment } & \multirow{2}{*}{ Concentration } & \multicolumn{3}{|c|}{ Disease severity at different days of intervals after inoculation } \\
\cline { 3 - 5 } & & 2 Days & 6 Days & 10 Days \\
\hline $\mathrm{T}_{1}$ & $2 \%$ & 38.06 & 40.90 & 48.00 \\
\hline $\mathrm{T}_{2}$ & $2 \%$ & 31.43 & 35.85 & 40.71 \\
\hline $\mathrm{T}_{3}$ & $2 \%$ & 25.01 & 30.90 & 36.87 \\
\hline $\mathrm{T}_{4}$ & $2 \%$ & 19.70 & 24.55 & 28.10 \\
\hline $\mathrm{T}_{5}$ & $2 \%$ & 17.75 & 23.40 & 25.30 \\
\hline $\mathrm{T}_{6}$ & $2 \%$ & 16.95 & 22.68 & 24.08 \\
\hline $\mathrm{T}_{7}$ & $2 \%$ & 16.70 & 21.87 & 23.35 \\
\hline $\mathrm{T}_{8}$ & $2 \%$ & 15.90 & 20.70 & 22.65 \\
\hline $\mathrm{T}_{9}$ & & 43.02 & 48.65 & 57.00 \\
\hline $\mathrm{SE}$ & & 4.324 & 3.240 & 8.663 \\
\hline C.D.P=(0.05) & & 3.600 & 3.116 & 5.095 \\
\hline
\end{tabular}

Table.3 Effect of calcium chloride as inducer on total soluble protein in potato leaves at different Days of interval after inoculation during pathogenesis ( $\mathrm{mg} / \mathrm{g}$ of fresh leaves)

\begin{tabular}{|c|c|c|c|c|c|c|c|}
\hline \multirow{2}{*}{ Treatments } & \multirow{2}{*}{ Concentrate } & \multicolumn{5}{|c|}{$\begin{array}{l}\text { Soluble protein content at different days } \\
\text { of interval (mg/g of fresh leaves) }\end{array}$} & \multirow{2}{*}{$\begin{array}{c}\text { \% increase over control } \\
\text { (at } 10 \text { days) }\end{array}$} \\
\hline & & $\begin{array}{c}2 \\
\text { Days }\end{array}$ & $\begin{array}{c}4 \\
\text { Days }\end{array}$ & $\begin{array}{c}6 \\
\text { Days }\end{array}$ & $\begin{array}{c}8 \\
\text { Days }\end{array}$ & $\begin{array}{c}10 \\
\text { Days }\end{array}$ & \\
\hline $\mathrm{T}_{1}$ & $2 \%$ & 31.75 & 7 & 33.80 & 33.97 & 32.34 & 66.03 \\
\hline $\mathrm{T}_{2}$ & $2 \%$ & 31.83 & 33.74 & 33.91 & 34.10 & 32.44 & 65.90 \\
\hline $\mathrm{T}_{3}$ & $2 \%$ & 31.92 & 33.83 & 34.02 & 34.22 & 32.56 & 65.78 \\
\hline $\mathrm{T}_{4}$ & $2 \%$ & 32.10 & 33.92 & 34.17 & 34.31 & 32.69 & 65.69 \\
\hline$T_{5}$ & $2 \%$ & 32.13 & 34.06 & 34.23 & 34.43 & 32.79 & 64.94 \\
\hline $\mathrm{T}_{6}$ & $2 \%$ & 32.40 & 34.18 & 34.32 & 34.51 & 32.90 & 65.49 \\
\hline $\mathrm{T}_{7}$ & $2 \%$ & 32.42 & 34.33 & 34.41 & 34.58 & 33.05 & 65.42 \\
\hline $\mathrm{T}_{8}$ & $2 \%$ & 32.50 & 34.53 & 34.50 & 34.68 & 33.10 & 65.32 \\
\hline $\mathrm{T}_{9}$ & & 21.87 & 23.75 & 23.85 & 24.15 & 23.44 & - \\
\hline $\mathrm{SE}$ & & 2.584 & 3.051 & 2.677 & 2.616 & 1.188 & - \\
\hline C.D $(0.05 \%)$ & & 2.783 & 3.107 & 2.832 & 2.800 & 1.887 & - \\
\hline
\end{tabular}


Table.4 Effect of calcium chloride as inducer on total phenol in potato leaves at different days of Intervals during pathogenesis (mg/g of fresh leaves)

\begin{tabular}{|c|c|c|c|c|c|c|c|}
\hline \multirow{2}{*}{ Treatment } & \multirow{2}{*}{ Con. } & \multicolumn{5}{|c|}{$\begin{array}{c}\text { Total phenol content at different days of } \\
\text { interval(mg/g of fresh leaves) }\end{array}$} & \multirow{2}{*}{$\begin{array}{c}\text { Per cent increased over control } \\
\text { (at 10 days) }\end{array}$} \\
\cline { 3 - 8 } & & 2 Days & 4 Days & 6 Days & 8 Days & 10 Days & 49.68 \\
\hline $\mathrm{T}_{1}$ & $2 \%$ & 2.18 & 2.20 & 2.31 & 2.43 & 2.35 & 57.96 \\
\hline $\mathrm{T}_{2}$ & $2 \%$ & 2.25 & 2.30 & 2.43 & 2.51 & 2.48 & 60.50 \\
\hline $\mathrm{T}_{3}$ & $2 \%$ & 2.30 & 2.36 & 2.48 & 2.27 & 2.52 & 65.60 \\
\hline $\mathrm{T}_{4}$ & $2 \%$ & 2.35 & 2.41 & 2.54 & 2.65 & 2.60 & 71.97 \\
\hline $\mathrm{T}_{5}$ & $2 \%$ & 2.39 & 2.47 & 2.51 & 2.72 & 2.70 & 72.61 \\
\hline $\mathrm{T}_{6}$ & $2 \%$ & 2.46 & 2.50 & 2.64 & 2.75 & 2.71 & 76.43 \\
\hline $\mathrm{T}_{7}$ & $2 \%$ & 2.55 & 2.58 & 2.72 & 2.86 & 2.77 & 77.07 \\
\hline $\mathrm{T}_{8}$ & $2 \%$ & 2.57 & 2.62 & 2.74 & 2.87 & 2.78 & - \\
\hline $\mathrm{T}_{9}$ & & 1.12 & 1.18 & 1.45 & 1.68 & 1.57 & - \\
\hline $\mathrm{SE}$ & & 0.108 & 0.132 & 0.142 & 0.121 & 0.126 & - \\
\hline C.D.P=(0.0) & & 0.570 & 0.629 & 0.652 & 0.601 & 0.616 & \\
\hline
\end{tabular}

Table.5 Correlation of disease severity with total soluble protein and phenol content of potato leaves

\begin{tabular}{|l|c|c|c|}
\hline \multirow{4}{*}{$\begin{array}{c}\text { Biochemical } \\
\text { parameters }\end{array}$} & $\begin{array}{c}\text { Days after Pathogen } \\
\text { inoculation }\end{array}$ & $\begin{array}{c}\text { Correlation } \\
\text { Coefficient (r) } \\
\text { With disease }\end{array}$ & $\begin{array}{c}\text { Regression } \\
\text { Equation }\end{array}$ \\
\hline \multirow{3}{*}{$\begin{array}{c}\text { Total soluble } \\
\text { Protein }\end{array}$} & 2 days & -0.5087 & $\mathrm{Y}=40.2134$ \\
\cline { 2 - 4 } & 4 days & -0.5095 & $\mathrm{Y}=39.1227$ \\
\cline { 2 - 4 } & 6 days & -0.5102 & $\mathrm{Y}=39.3198$ \\
\cline { 2 - 4 } & 8 days & -0.5279 & $\mathrm{Y}=39.5485$ \\
\hline Total phenol & 10 days & -0.5105 & $\mathrm{Y}=39.6303$ \\
\cline { 2 - 4 } & 2 days & -0.9879 & $\mathrm{Y}=3.9539$ \\
\cline { 2 - 4 } & 4 days & -0.9887 & $\mathrm{Y}=3.9568$ \\
\cline { 2 - 4 } & 6 days & -0.9926 & $\mathrm{Y}=3.9797$ \\
\cline { 2 - 4 } & 8 days & -0.9946 & $\mathrm{Y}=3.9064$ \\
\hline
\end{tabular}

\section{Total phenol}

The result presented in table 5 shows that all the treatment significantly increased the total phenol content as compared to control at 2, 4, 6 and 8 days of pathogen inoculation. The maximum amount of total phenol contents was found in $\mathrm{T}_{8}$ treatment, representing the value $2.57 \mathrm{mg} / \mathrm{g}$ of fresh leaves, $2.62 \mathrm{mg} / \mathrm{g}$ of fresh leaves, $2.74 \mathrm{mg} / \mathrm{g}$ of fresh leaves, 2.87 $\mathrm{mg} / \mathrm{g}$ of fresh leaves and $2.78 \mathrm{mg} / \mathrm{g}$ of fresh leaves of fresh leaves at 2,4,6,8 and 10 days of pathogen inoculation. Among the treatments, the minimum amount of total phenol contents was found in $\mathrm{T}_{1}$ treatment, representing the value $2.18 \mathrm{mg} / \mathrm{g}$ of fresh leaves, $2.20 \mathrm{mg} / \mathrm{g}$ of fresh leaves, $2.31 \mathrm{mg} / \mathrm{g}$ of fresh leaves, $2.43 \mathrm{mg} / \mathrm{g}$ of fresh leaves and $2.35 \mathrm{mg} / \mathrm{g}$ of fresh leaves at 2,4,6,8 and 10 days of pathogen inoculation. The per cent increase of total phenol over control was highest in $\mathrm{T}_{8}$ treatment (77.07), followed by $\mathrm{T}_{7}$ treatment (76.43). Phenols are well known antifungal, antibacterial and antiviral compound. Matern and Kneusal (1988) suggested that the first stage of defense mechanism involve a rapid a rapid accumulation of phenol at the infection site which restricts or slow the growth of the pathogen. Gridhr et al., (2008) reported that phenol was found increase in rice leaf after treatment with biotic inducer. Mishra et al., 
(2010) also reported that increased total phenol content was found on varieties of wheat showing resistance to spot blotch.

\section{Correlation co-efficient and regression equation}

The biomolecules changes in potato leaves at different days and disease severity of corresponding day showed that reduced disease severity was associated with increase soluble protein and total phenol content. A negative correlation (r) $-0.5087,-0.5095$, $0.5102,-0.5279$ and -0.5105 was found between disease severity and soluble protein content. Similarly, correlation between disease severity and total phenol content also showed negative correlation. The corresponding simple regression equation also showed the negative relation between total protein and disease severity as well as total phenol and disease severity. Similar observations were also found in rice against brown leaf spot (Girdhari et al., 2010) in tomato against Fusarium wilt (Arzoo et al., 2010, Biswas et al., 2012), in wheat against spot blotch (Mishra et al., 2011).

It may be concluded from the present finding that $\mathrm{CaCl}_{2}$ have inducing effect of reduce disease severity of potential to control Late blight of potato. It has also ability to synthesize some defense compound like total soluble protein total phenol etc. resulted defense response in plant. Thus it may be a better alternative of disease management in sustainable agriculture.

\section{References}

Abd-El-Kareem, F. (2007). Potassium or sodium bicarbonate in combination with Nerol for for controlling early blight disease of potato plants under laboratory, greenhouse and field conditions. Egyptian Journal of
Phytopathology. 351: 73-86.

Abd-El-Kareem, F., Abd-Alla, M. A. and ElMohamedy, R. S. R. (2001). Induced Resistance in Potato Plants for Controlling Late Blight Disease under Field Conditions. Egypt. J. Phytopath., 29(2): 29-41.

Aglika Edreva (2004). A novel strategy for plant protection: Induced resistance. Journal of Cell and Molecular Biology 3: 61-69.

Arimoto, Y., Homma, Y. and Misato, T. (1997).The effect of sodium hydroen carbonate on the occurrence of citrus storage diseases. Journal of Pesticides Science 2(2): 163-167.

Biswas, S. K., Pandey, N. K. and Rajik, M. (2012). Induction of Defense Response in Tomato against Fusarium Wilt through Inorganic Chemicals as Inducers. J. Plant. Patho. Microb. 3, 4.

Gautam, H. R. (2009). Effect of climate change on rural India. Kurukshetra, 57 (9):3-5.

Horst, R. K., Kawamoto, S. O. and Porter, L. L. (1992). Effect of sodium bicarbonate and oils on the control of powdery mildew and black spot of roses. Plant Disease, 76(3):247-251.

Karabulut, O. A., Smilanick, J. L., Gabler, F. M., Mansour, M. and Droby, S. (2003). Near-harvest applications of Metschinkowia fructicola, ethanol and sodium bicarbonate to control postharvest diseases of grape in central California. Plant Disease, 87(11): 13841389.

Kuc, J. (2001). Concepts and direction of induced systemic resistance in plants and its application. Eur J Plant Pathol. 107, 7-12.

Lyon, G. D., Reglinski, T. and Newton, A. C. (1995). Novel disease control compounds: the potential to "immunize" plants against infection. Plant Pathol. 44, 407-427. 
Rajik, Mohd., Biswas, S. K. and Shakti, S. (2012). Biochemical basis of defense response in plant against Fusarium wilt through bio-agents as inducers. African Journal of Agriculture Research, 7(43):5849-5857.

Scott, G. and Suarez, V. (2011). Growth rates for potato in India 1961-2009 and their implications for industry. Potato $J$. 38(2): 100-112.

Smilanick, J. L., Mansour, M. F. and Sorenson, D. (2006). Pre- and postharvest treatments to control green mould of citrus fruit during ethyline degreening. Plant Disease, 90 (1):8996.

Strobel, N. E. and Kuc, J. (1995). Chemical and biological inducers of resistance to pathogens protect cucumber and tobacco plants from damage caused by paraquat and cupric chloride. Phytopathology. 85, 1306-1310.

Tally, A., Oostendorp, M., Lawton, K., Staub, T. and Bassy, B. (1999). Commercial development of elicitors of induced resistance to pathogens. In: Inducible Plant Defenses against Pathogens and Herbivores: Biochemistry, Ecology, and Agriculture. Agrawal AA, Tuzun S and Bent E (Eds). Amer. Phytopathol. Soc. Press, St. Paul, MN (USA). 357-369.

Ziv, O. and Zitter, T. A. (1992). Effect of bicarbonates and film-forming polymers on cucurbit foliar diseases. Plant Disease. 76, 513-517.

\section{How to cite this article:}

Surjeet Kumar, S.K. Biswas, Virendra Kumar, Kishan Lal, Anuj Bansal and Tilak Chowdary, V. 2017. Induced Resistance in Potato against Late Blight Caused by Phytophthora Infestans (Mont.) De Bary, Through Calcium Chloride. Int.J.Curr.Microbiol.App.Sci. 6(8): 410-417. doi: https://doi.org/10.20546/ijcmas.2017.608.054 